\title{
David Oliver: l've nothing against golf
}

As a kid in Manchester I'd hack my way around municipal short courses in public parks with rented clubs. And I enjoy watching the Open and the Masters on TV. But that's the closest I've got to golf club membership.

Non-medical media watchers in the United Kingdom might have me pegged as "below par" here. Surely all doctors have a membership card in our wallet and kit in the car, ready to tee off at a moment's notice with a group of well heeled colleagues? And what better time, surely, than when at the public's expense-perhaps when we're on call or meant to be in clinic on a Friday afternoon? Shameful.

A recent Times feature on emergency readmissions to hospital had Patient Concern's Roger Goss opining that these were due to doctors working "on the golf course with their mobile phones." Cristina Odone said in the Telegraph, "Doctors should get off the golf course and onto the wards," ${ }^{2}$ and the vitriolic online responses evinced equally uninformed resentment.

These examples symbolise the myths and clichés in the narrative surrounding the current stand-off between the Department of Health and the BMA over contract changes and seven day working. Golf club membership in England is $83 \%$ male and only $3 \%$ non-white. ${ }^{3}$ It's seen as shorthand for wealth and exclusivity, conservative with a small and a large $\mathrm{C}$. This is exemplified by the BBC's "voice of golf," Peter Alliss, and his reactionary on-air gaffes. ${ }^{4}$ Also, it's often said that doctors are "naturally conservative."

Yet the General Medical Council census showed that half of UK doctors are women and that only half are white. ${ }^{5}$ And openly anti-Conservative campaigns against the growing marketisation of the NHS, including those from the BMA itself, indicate that many doctors are hardly of the political right. ${ }^{6}$

When I' $m$ in the hospital on a weekend I work pretty much flat out for 12 hours. There'd be some slow play if I tried to see
30-40 new acute patients from a golf course. It's the same for most doctors, junior or senior, in many acute specialties. But this didn't stop the health secretary, Jeremy Hunt, saying that we had a "nine to five weekday culture" and had "lost a sense of vocation.",

I've recently asked more than 100 doctor colleagues whether they play golf, and fewer than 1 in 20 said yes. Popular debates about doctors' terms and conditions should be based on the realities of the modern medical workforce, our values, and our work patterns - and not on fantasy.

Competing interests: I have read and understood the BMJ policy on declaration of interests and have no relevant interests to declare.

Provenance and peer review: Commissioned; not externally peer reviewed.

Follow David on Twitter, @mancunianmedic

1 Smyth C. Patients released on Sunday most likely to return to hospital. Times 2015 Oct 1.

2 Odone C. Doctors should get off the golf course and into the wards. Telegraph $2012 \mathrm{Dec}$ 17. www.telegraph.co.uk/comment/9749532/Doctors-should-get-off-the-golf-course-andinto-the-wards.html.

3 England Golf. Golf club membership questionnaire results booklet 2012. Available at: www.englandgolf.org/page. asp x? ? sitesectionid=448.

4 Crossley L. BBC's voice of golf Peter Alliss causes new sexism storm by saying Open winner's wife would spend his winnings on a new kitchen. Mail Online 2015 Jul 21. www. dailymail.co.uk/news/article-3169333/BBC-s-voice-golf-Peter-Alliss-causes-new-sexismstorm-saying-Open-winner-s-wife-spend-winnings-new-kitchen.html.

5 General Medical Council. List of registered medical practitioners-statistics. Oct 2015. www.gmc-uk.org/doctors/register/search_stats.asp.

6 BMA. No more games with the NHS. 2015. http://bma.org.uk/working-for-change/nhscampaign-2015.

7 Triggle N. Jeremy Hunt: Doctors "must work weekends." BBC News 2015 Jul 16. www. bbc.co.uk/news/health-33542940.

Cite this as: BMJ 2015;351:h5796

(c) BMJ Publishing Group Ltd 2015 